\title{
SECURITY MANAGEMENT OF UNIVERSITY CAMPUSES
}

\author{
Constantin OPREAN, Mihail ȚÎȚU, Cristina TĂNĂSESCU \\ "Lucian Blaga" University of Sibiu, Romania \\ constantin.oprean@ulbsibiu.ro,mihail.titu@ulbsibiu.ro, \\ cristina.tanasescu@ulbsibiu.ro
}

\begin{abstract}
The paper is approaching a sensitive topic which the whole society is facing, namely the security at a macro and micro-economic level. In this context, increasing the level of terrorism at all levels requires important measures to prevent the acts of terrorism and of providing a security that allows the development of all entities in the society. University offsets represent areas of agglomeration of young students living together, susceptible to challenging actions and to acts of terrorism that may occur at any time. The paper approaches a systemic and systematic thinking of untried actions to be taken for these structures, components of the university.
\end{abstract}

Keywords: security, management, risks, university campus, attack

\section{Introduction}

The University is one of the most complex organizations in our society, with very diverse human resources corresponding to the professional fields they are active in, its diverse culture and its involvement in the community life and its mission to train specialized human resources, necessary for the development of the society and for social renewal. This organization is a balancing factor in society, an example of morality and impartiality in all the fields of contemporary life, which is continuously transforming and faces the attack of environmental positive and negative factors.

For this reason, in order to maintain its status of unaltered organization of our society, all decision-making factors and civic bodies must get involved in protecting it, alongside the church, the army, which represent the building and stability pillars of all our nations and societies.

In accordance to article 126, paragraph 3 of Law no. 1/2011 [7], on national education, "university premises are intangible. Access to the university premises is only allowed under the conditions provided by law and by the university charter."

The authors believe that university premises are synonymous with the concept of campus, which, according to the Explanatory Dictionary of Romanian $\left(2^{\text {nd }}\right.$ edition, revised and amended - DEX 2009), is defined as "Complex universitar cuprinzând construcții și dotări pentru învățământ, cercetare, locuit, agrement etc.", and, according to the New Dictionary of Romanian (Nodex 2002)[1], a campus is a "Teren pe care este amplasată o instituție de învăţământ superior cu toate dotările pentru cercetare, locuit, agrement etc.", of course comprising all the features necessary for the educational process.

Risks that may endanger ordinary university life [4], as well as the life of the community we live in and of the entire society can be grouped as follows:

- natural risks:

$$
\circ \text { dangerous weather phenomena }
$$


(storms, floods, tornadoes, draught, frost, etc.);

o fires;

o geological phenomena (landslides, earthquakes, floods, etc.);

- technological risks:

$\circ$ accidents, damages, explosions and fires;

o collapsing constructions, technological equipment, dams, works, etc.;

o damaged public utilities systems;

o objects falling from the sky;

o unexploded ammunition, etc.;

- biological risks:

o epidemics;

o epizooties/zoonosis;

- chemical risks:

o contamination with various chemicals;

o nuclear contaminations;

- risks from terrorist and organized crime attacks.

Risk is defined as the mathematical estimation of the probability that human lives are lost and human health is affected, that material, environmental, social and psychological damage is produced over a reference period, i.e. future period, and in a given area [5].

In the context of ensuring a quality life in university campuses, risk management as a component of security management represents the systematic implementation of policies, procedures and practices related to the management of communication, consultation, context establishing, as well as of evaluation, handling, monitoring and reevaluation of risk (Government Decision no. 557/03.08.2016 on risk type management; SR EN 13010/2010).

\section{Systems of campuses organization}

To ensure normal working conditions in university campuses, optimum security conditions must be put in place, i.e. protected it from any danger, in order to ensure the feeling of trust and peace granted by the absence of any danger.
Under the present conditions of university campus organization, security management acquires different particularities. Thus, at a global level, university campuses are classified as follows:

- university campuses outside of the community;

- university campuses integrated in the community.

The concept of university campuses outside of the community provides the advantage that all its structural components work optimally, as they are projected and built based on the criterion of optimum operation and on the integration of all activities in a unitary structure of university and nonuniversity life. Examples of such campuses: Cambridge University Campus, Sibiu Land Forces Academy. The great disadvantage is that university life is isolated from community life.

The concept of university campus integrated in the community has the advantage that university life is part of community life and that the two interact, benefitting the community.

The great disadvantage is that the building infrastructure is mostly inoperative, and, in order to ensure minimum operability conditions, adaptation works - usually inefficient - are necessary.

The big advantage of this type of university campuses is that it integrates university and community life. An example is the campus of "Lucian Blaga" University of Sibiu.

From the point of view of the security of the university campus, the most recommended solution is that of a university campus in an isolated location, outside of the local community, comprising all university assets and activities, allowing for better supervision.

\section{Securities of university capuses}

From the point of view of security management, aiming to prevent and to manage environment, technological, biological and chemical risks, bodies such 
as Inspectorates for Emergency Situations were set up in Romania through Government Decision no. 1492/2004, coordinated by the General Inspectorate for Emergency Situations, which is part of the National System for the Management of Emergency Situations, whose purpose is to monitor, evaluate, inform, warn, earlywarn, alert and implement the operational technical coordination emergency situations at national level.

In Romania, most recent cases were related to fires; for this reason, inspections regarding the way in which security permits are checked were generalized and intensified.

Terrorist and organized crime acts make up the most sensitive field nowadays.

Attack of education include:

- Attacks on students, academic staff, and education institutions, with a devastating impact.

Immediate effects can include death, injuries and the destruction of education facilities, as well as disrupted access to education. In the long term, attacks can lead to diminished education quality, loss of teachers and academics, and weakened education systems. The quality and relevance of higher education can be degraded, and research and innovation curtailed. Weakened education adversely affects a country's economic, political and social development, and undermines efforts to reduce poverty and improve maternal and child health.

Presently, as attacks on university campuses have intensified, international structures were set up to protect higher education; through their actions, these structures aim at promoting the members of the academic community and promoting academic freedom.

An example is the Global Coalition to Protect Education from Attack (GCPEA), established in 2010, including bodies such as:

- United National Educational, Scientific and Cultural Organization (UNESCO);
- United Nations High Commissioner for Refugees (UNHCR);

- United Nations International Children's Emergency Fund (UNICEF);

- Council for At-Risk Academics (CARA);

- Protect Education in Insecurity and Conflict (PEIC);

- Institute for International Education (IIE);

- Human Rights Watch (HRW);

- Scholars at Risk;

- Save the Children, etc., whose mission is to advocate for the protection of students, teachers, schools and universities from attack.

Their goals are:

- to highlight the incidence and impact of attacks on education in conflict and insecurity among key actors and to cultivate public support for safe education;

- to promote better systems to monitor and report attacks on education;

- to promote effective programmes and policy to protect education from attacks, including prevention and response;

- to encourage adherence to existing international laws protecting education and the strengthening of international norms and standards, as needed;

- to fight impunity for attacks on education by promoting and supporting a range of accountability measures.

Attacks on education may violate international humanitarian and criminal law and may constitute war crimes or crimes against humanity. The use of education by state security forces and other armed groups may place students and academic staff at risk of attack. This is why we put forward some recommendations to protect education from attack:

- monitor attacks on education and the state: local organizations and international agencies should rigorously monitor attacks on education and use the data to provide informed responses; 
- put in place preventive measures and response systems: the ministries and education institutions should put in place preventive measures and response systems, and adopt and implement the best practices to protect education from attack;

- the state should ensure that its domestic law criminalized all elements of attack on education in line with international humanitarian and human rights laws;

- domestic, regional and international tribunals should consider violations that constitute attacks against education in relevant investigations, and pursue and prosecute serious cases.

\section{Security management of university campuses}

In order to improve the security management of education, the general safety measures must be taken into consideration [5]:

- coordination between educational institutions and the national security body, etc.;

- security cameras and other technological surveillance;

- armed or unarmed security guards;

- criminal code, national security law or other relevant regulatory framework for the protection of higher education;

- security drills or other types of trainings for staff and students, teaching them how to react in case of attack;

- police visits to university campuses;

- establishing security committees in higher education institutions;

- emergency response measures, such as first aid kits, fire escapes, etc;

- including security in laws protecting and upholding education and university campuses or freedom;

- legislation to protect the institutional autonomy of higher education.

At the same time, it is necessary to take measures to protect university campuses:
- workshops and awareness-raising efforts on the role of academic staff dealing with psychological war and terrorism;

- strengthening higher education infrastructure, including building, renovating or improving it, and facility equipment;

- informing security authorities about the measures taken to protect institutions;

- establishing emergency response mechanisms in case of attack;

- alternative means of transport;

- information sharing mechanisms between higher education institutions and national security bodies for rapid response in case of attack;

- safety assessment and risk analysis mechanisms;

- plans to continue education in university campuses in case part of it is unsafe or otherwise out of use;

- counselling and referral mechanisms in case of attack;

- negotiation with armed groups;

- collaboration with the Red Cross or other relevant bodies in case of emergency aid, evacuation, etc.;

- policies or other efforts to make higher education inclusive and accessible;

- providing assistance to victims of attacks;

- higher education grants to support students and academic staff during times of crisis.

\section{Conclusions}

To conclude, our society can only develop in a sustainable manner only if we create favorable conditions for the sustainable development of universities as integrated part of global development. The development and consolidation of university-like organizations greatly depends on ensuring a good management of university campus security. 


\section{References}

[1] DEX '09, Dicționarul explicative al limbi române (ediția a II-a revizuită și adăugită), 2009.

[2] NODEX, Noul dictionar al limbii române, 2002.

[3] ISO/IEC 27001/2013 Sisteme de Managementul Calității, 2013.

[4] SR EN 31010/2010 Managementul riscului. Tehnici de evaluare a riscului, 2010.

[5] HG 557/2016, Managementul tipurilor de risc, 2016.

[6] HG 1490/2004, Regulamentul de organizare și funcționare și a organigramei IGSU, 2004.

[7] Legea nr. 1/2011, Legea Educației Naționale, 2011.

[8] Protecting Higher Education from Attack, GCPEA Conference, Paris, April $21^{\text {st }} 2016$. 